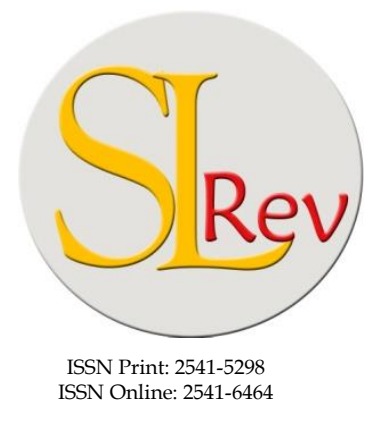

ISSN Online: $2541-6464$

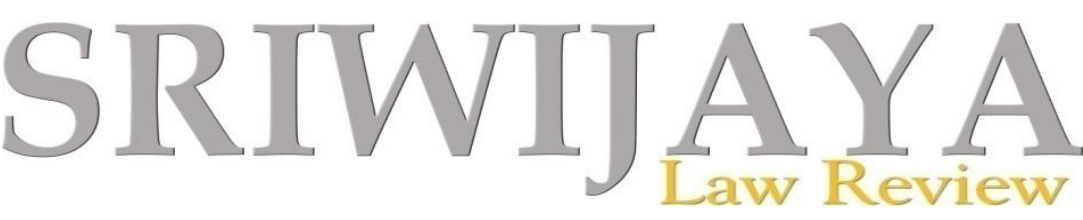

Editorial Office: Faculty of Law, Sriwijaya University

Jalan Srijaya Negara, Palembang, South Sumatra 30139, Indonesia.

Phone: +62711-580063Fax: +62711-581179

E-mail: sriwijayalawreview@unsri.ac.id| sriwijayalawreview@gmail.com

Website: http://journal.fh.unsri.ac.id/index.php/sriwijayalawreview

\title{
The Criticism of Land Procurement Law to Improve Landowners Welfare in Indonesia
}

\author{
Fifik Wiryani, ${ }^{\mathrm{a}^{*}}$ and Mokhammad Najih ${ }^{\mathrm{a}}$
}

a* Corresponding Author. Faculty of Law, University of Muhammadiyah Malang, Malang, Indonesia. E-mail: fwiryani2016@gmail.com

b Chairman of the Ombudsman of the Republic of Indonesia \& Faculty of Law, University of Muhammadiyah Malang, Malang, Indonesia.E-mail: najihumm@gmail.com

\begin{tabular}{|c|c|}
\hline Article & Ibstract \\
\hline $\begin{array}{l}\text { Compensation; Land } \\
\text { Procurement Law; Land } \\
\text { Right; Landowner Wel- } \\
\text { fare. } \\
\text { Article History } \\
\text { Received: Feb 20, 2021; } \\
\text { Reviewed: Jul 21, 2021; } \\
\text { Accepted: Jul 28, 2021; } \\
\text { Published: Jul 31, 2021. }\end{array}$ & $\begin{array}{l}\text { This study is to conduct a juridical analysis of the implications of Law No. } 2 \\
\text { of } 2012 \text { on Land Procurement for Development for the Public Interest to im- } \\
\text { prove the welfare of landowners after the release of land rights. The focus of } \\
\text { the study is on the arrangement of indemnity from the aspects of assessors, } \\
\text { indemnity assessment, and deliberation on the determination of indemnity. } \\
\text { The research approach uses normative juridical, with secondary data sourced } \\
\text { from primary legal materials and secondary legal materials collected from } \\
\text { March to July 2020. The data is analysed using content analysis combined } \\
\text { with prescriptive analysis. As a result, this research proposes the arrangement } \\
\text { of compensation in the Law on Land Procurement for the Development of the } \\
\text { Public Interest. These arrangements are included the material determination of } \\
\text { assessors, the value of compensation, deliberation of the determination of } \\
\text { compensation, and the custody of compensation (consignment) in the Law on } \\
\text { Land Procurement which is inconsistent with the principles and principles of } \\
\text { land procurement that should be as the basis and guidelines for the formula- } \\
\text { tion of norms. }\end{array}$ \\
\hline \multicolumn{2}{|c|}{$\begin{array}{l}\text { (C)2021; This is an Open Acces Research distributed under the term of the Creative Commons Attribution License } \\
\text { (https://Creativecommons.org/licences/by/4.0), which permits unrestricted use distribution, and reproduction in any } \\
\text { medium, provided the original works is properly cited. }\end{array}$} \\
\hline
\end{tabular}

\section{INTRODUCTION}

Land acquisition for public purposes is defined as the activity of providing land for the benefit of the nation, state and society that the government must realize by providing proper and fair compensation to people who are entitled and used to the maximum extent for prosperity. ${ }^{1}$ Land acqui-

1 Mukmin Zakie, 'Konflik Agraria Yang Tak Pernah Reda', Legality: Jurnal Ilmiah Hukum, 24.1 (2017), 40 $<$ https://doi.org/10.22219/jihl.v24i1.4256>. 
sition is the primary means used by the government in meeting the development needs of the public interest in Indonesia. ${ }^{2}$

In order to create a just and prosperous society based on Pancasila and 1945 Constitutions, national development in various sectors is needed, namely development in the political, economic, social, cultural, defence and security sectors. One of the government's efforts to develop the country is by building facilities for the public interest. The land is a significant component that plays an important role and determines the success or failure in developing public interest.

Three major problems occurred during the early reign of Joko Widodo-Jusuf Kalla (JokowiJK) presidential, namely: 1) the deterioration of state authority; 2) weakening national economic sectors; and 3) widespread intolerance and national personality crisis as a counter strategy, Jokowi-JK presidential creates Nawacita program. Nawacita contradicts the mainstream development paradigm concept, which supports economic growth as Indonesia's development main goal. ${ }^{3}$

Nawacita adopted "Trisakti" from President Sukarno, including political sovereignty, economic independence, and cultural identity. The Nawacita program is including 1) bringing back the state to protect the entire nation and providing security to all citizens; 2) build clean, effective, democratic and reliable governance; 3) reject weak states by reforming systems and enforcing a corruption-free, dignified and trusted law; 4) creating economic independence by driving the domestic economy as strategic sector; 5) developing Indonesia from the periphery; 6) increasing community's productivity and competitiveness; 7) improving the quality of people's lives through education and training advancement; 8) revolutionizing the nation's character through policy rearrangement of national education curriculum; 9) strengthen diversity and Indonesian social restoration.

Infrastructure drives economic growth in national and regional development to play an essential role in improving the quality of life and community welfare. ${ }^{4}$ Jokowi-JK's regime prioritizes infrastructure development, fundamental infrastructure that is publicly used, such as electricity, clean water and roads. Thus, Indonesia can accelerate its economic development, as written on the third, fourth and fifth Nawacita programs, and attract foreign investors. A study conducted by Cut Nanda Keusuma and Suriani found that electricity and roads positively and significantly affected economic growth in 26 provinces. Tatan Sukwika's research supported this study, which found a strong positive correlation between GDP gap per capita and infrastructure gap between provinces. ${ }^{5}$

Infrastructure development during the Jokowi-JK government has been done seriously. During 2014 - 2018 the government has escalated its annual budget as much as 2.078.9078.9 Trillion Rupiahs in total. Infrastructure development has been done by the Jokowi-JK government, includ-

2 Adinda Putri Jade, Diah Nadia Putri, and Sholahuddin Al-Fatih, 'Perizinan Membuka Tanah Negara Di Kota Balikpapan', Supremasi Hukum: Jurnal Penelitian Hukum, $29.2 \quad$ (2020), 102-30 <https://doi.org/https://doi.org/10.33369/jsh.29.2.\%25p>.

3 (Soleman and Noer 2017:1964).

4 Presiden RI, Peraturan Presiden Nomor 71 Tahun 2012 Tentang Penyelenggaraan Pengadaan Tanah Bagi Pembangunan Untuk Kepentingan Umum (Indonesia: Lembaran Negara Republik Indonesia Tahun 2012 Nomor 156, 2012); Harry Kurniadi Atmaja and Kasyful Mahalli, 'Pengaruh Peningkatan Infrastruktur Terhadap Pertumbuhan Ekonomi Di Kota Sibolga', Jurnal Ekonomi, 3.4, 248-66; Novi Maryaningsih, Oki Hermansyah, and Myrnawati Savitri, 'Pengaruh Infrastruktur Terhadap Pertumbuhan Ekonomi Indonesia', Buletin Ekonomi Moneter Dan Perbankan, 17.1 (2014), 61-98.

5 Cut Nanda Keusuma and Suriani Suriani, 'Pengaruh Pembangunan Infrastruktur Dasar Terhadap Pertumbuhan Ekonomi Di Indonesia’, ECOsains: Jurnal Ilmiah Ekonomi Dan Pembangunan, 4.1 (2015), 1-18. 
ing: ${ }^{6}$ 1) Construction of 3,432 kilometres of national roads and 947 kilometres of toll roads; 2) Construction of 39.8 kilometres of the bridge and 41 suspension bridges; 3) Railway line construction $754.59 \mathrm{~km}^{2}$; 4) Construction of Light Rail Transit (LRT) in South Sumatra, Jakarta and Jabodetabek areas; 5) Establishment of Mass Rapid Transit (MRT); 6) Construction of 10 airports; 7) Reconstruction of 408 airports in disaster-prone, isolated and border areas; 8) Built-in 27 ports, and 9) Sixty-five dams.

The land is a limited natural resource ${ }^{7}$ unable to develop or expand. In addition, land has economic value and cultural, social, political, and defence-security value. Hasan Basri said that land has a dual function as social assets and capital assets. ${ }^{8}$ rest, cultivate, housing, irrigation, schools, public roads, offices and places of focus for humans. ${ }^{9}$

Land is the essential capital for human life, which has the function of production and nonproduction. ${ }^{10}$ land is fascinating, and there will be no end because the land issue is related to the issue of conflict of interest between individuals, communities and the state. ${ }^{11}$ So important is land for human beings that land ownership is a human right (human rights) protected by international law and national law. In international law, the property right is regulated in the Universal Declaration of Human Rights, specifically in Article 17(1), which among other things, is the right to own property. Article 17(2) concerning the protection of his property is arbitrarily seized. Article 30 is on the protection of actions aimed at destroying any rights and freedoms.

In Indonesia, the protection of land rights is regulated in the 1945 Constitution Article $28 \mathrm{H}$ (4): "Everyone has the right to own private property, and such property rights should not be arbitrarily taken over by anyone" and Article 28G (1): "Everyone has the right to the protection of himself, family, honour, dignity, and property under his control, and entitled to a sense of security and protection from the threat of fear of doing or not doing something that is a fundamental right." As well as Law 39 of 1999 on Human Rights Article 36 paragraph (1) "Everyone has the right to own... by not violating the law," (2) "No one shall be arbitrarily and unlawfully deprived"; and (3) "Property has a social function".

Based on the construction of the law, land ownership also has a social function, among others, in the form of public interest development carried out by the state to realize a fair and prosperous society as mandated by the Constitution.

Based on the principle of State Control Rights (HMN) and Article 33 of the 1945 Constitution, a state has difficulty providing free state land because most of the land is already privately owned by individuals, legal entities, groups of people and indigenous peoples. ${ }^{12}$ So, often

6 'Jokowi Bangun 3.432 Km Jalan Nasional Dan 941 Km Jalan Tol'.

7 Ashar Sinilele, 'Tinjauan Yuridis Terhadap Pelaksanaan Pengadaan Tanah Bagi Pembangunan Untuk Kepentingan Umum Di Kota Makassar', Jurnal Al-Qadau, 4.1 (2017), 1-24.

8 Hasan Basri, 'Keadilan Dan Kepastian Hukum Bagi Pemegang Hak Atas Tanah Dalam Pengadaan Tanah Untuk Kepentingan Umum', IUS Kajian Hukum Dan Keadilan, 1.1 (2013), 77-93.

9 Sinilele.

10 Mukmin Zakie, 'Pengadaan Tanah Untuk Kepentingan Umum (Perbandingan Antara Malaysia Dan Indonesia)', Jurnal Hukum Edisi Khusus, 18 (2011), 187-206.

11 Ujang Bahar, 'Permasalahan Pembayaran Ganti Rugi Pengadaan Tanah Bagi Pelaksanaan Pembangunan Untuk Kepentingan Umum', Jurnal Hukum \& Pembangunan, $38.1 \quad$ (2008), 122 <https://doi.org/ 10.21143/jhp.vol38.no1.166>.

12 Muhamad Erwin, 'Reconstruction the Paradigm of Law and Justice on the Regulation of Right to Living Space of the Orang Rimba Tribe in Bukit Duabelas, Jambi Province', Sriwijaya Law Review, 2.1 (2018), 56 <https://doi.org/10.28946/slrev.vol2.iss1.110.pp56-68>. 
in the implementation of the development of the public interest is using land owned by the people. $^{13}$

The use of people's land for public interest development can be done by 4 (four) alternative mechanisms, namely: 1) the transfer of land rights based on treaty law; 2) voluntary release of land rights by the owner based on UUPA Article 27.a.2, Article 34.c, and Article 40.c.; 3) revocation of land rights by the state based on Article 18 UUPA and Law 20 of 1961 on the Revocation of Land Rights (Law on the Revocation of Land Rights); or 4) Land Procurement based on Law 2 the Year 2012 (Land Procurement Law). Among the four alternative land use of the people for the public interest, in practice, the mechanism of land procurement is the most cause problems.

In general, the problem of land procurement for public interest development is about the dissatisfaction of landowners with the amount of compensation given by land procurement organizers, as the results of Adhim's study in land procurement for the construction of the widening of the road Tambaklorok Village Semarang ${ }^{14}$ caused, among others, because the Assessor is not transparent about the size and assessment system of land procurement objects; land procurement organizers make the results of the assessment of the appraisal as the value of compensation, deliberation does not produce a compensation that has been concurred along with the limitation of the period of objection. ${ }^{15}$

The issue of land acquisition has led to a settlement to the judiciary. The judiciary has resolved 4,810 cases of civil disputes on land procurement and 6,280 criminal cases related to land acquisition. ${ }^{16}$ The object of the dispute in the civil decision of land procurement, among others, concerning the mechanism of deliberation that does not produce an agreement, ${ }^{17}$ the authority of the government to make a consignment of compensation to the District Court (PN) that is not based on the results of the agreement in deliberation. ${ }^{18}$

The implementation of land procurement for public interest development is carried out to ensure the availability of land for the implementation of public interest development but while ensuring the legal interests of landowners, to improve the welfare and prosperity of the nation, state, society by prioritizing humanitarian, democratic, and fair principles.

The three principles of land procurement for the development of the public interest then affirmed in ten principles of land procurement, namely: a. humanity; b. justice; c. benefits; d. cer-

${ }^{13}$ Alexandra Xanthaki, 'Lands Rights of Indigenous Peoples in South East Asia', Melbourne Journal of International Law, 4.1 (2003), 467-95.

14 Nur Adhim, 'Model Upaya Hukum Terhadap Ganti Kerugian Dalam Pengadaan Tanah Untuk Kepentingan Umum (Studi Kasus Pembangunan Jalan Tambaklorok, Kota Semarang)', Gema Keadilan, 6.1 (2019), 75 <https://doi.org/10.14710/gk.6.1.75-85>.

15 Sumral Buru Manoe, 'Konstruksi Hak Menguasai Negara Dalam Tata Laksana Pengadaan Tanah Bagi Kepentingan Umum Di Kabupaten Semarang', I.2 (2014), 228-36.

16 'Direktori Putusan Mahkamah Agung Republik Indonesia'.

17 Isdian Anggraeny and Sholahuddin Al-Fatih, 'Kata Sepakat Dalam Perjanjian Dan Relevansinya Sebagai Upaya Pencegahan Wanprestasi', De Lega Lata: Jurnal Ilmu Hukum, 5.1 (2020), 57-66 <https://doi.org/10.30596/dll.v5i1.3446>.

18 Dekie GG Kasenda, 'Ganti Rugi Dalam Pengadaan Tanah Untuk Kepentingan Umum', Jurnal Morality, 2.2 (2015), 1-21; Tami Rusli, 'Analisis Pelaksanaan Konsinyasi Ganti Rugi Pada Pengadaan Tanah', Keadilan Progresif, 9.1 (2018), 15-28; Marni Emmy Mustafa, 'Penawaran Pembayaran Tunai Dan Konsignasi Di Pengadilan Untuk Pengadaan Tanah Bagi Pembangunan Untuk Kepentingan Umum', 2019, pp. 1-17; Rahayu Subekti, 'Kebijakan Pemberian Ganti Kerugian Dalam Pengadaan Tanah Bagi Pembangunan Untuk Kepentingan Umum', Yustisia, 5.2 (2016), 376-94; Urip Santoso, 'Penyelesaian Sengketa Dalam Pengadaan Tanah Untuk Kepentingan Umum', Perspektif, 21.3 (2016), 188-98; Sinilele. 
tainty; e. openness; f. agreement; g. participation; h. welfare; i. sustainability; and j. harmony. The most urgent and essential thing regulated by the Land Procurement Law is the issue of "indemnity" because the compensation has direct or indirect implications for the continuity of the welfare level of landowners to be decreased, stagnant or increased. The Land Procurement Act defines indemnity as a proper and fair replacement to the appropriate parties in the land procurement process. The provision of indemnity is stipulated in Article 31 to Article 44 of the Land Procurement Law. Potentially trouble-causing indemnity arrangements are about indemnity assessment, deliberation on the determination of compensation, objections of the Rightful Party regarding the form and/or amount of damages, and custody (contingency) indemnity in the District Court.

This research has a powerful novelty because several research/previous studies did not explain toward Land Procurement Act and its impact on improving the welfare of landowners in Indonesia. Djanggih and Salle, in their research in 2017, founded that land acquisition regulations in the regions are regulated based on the principle of regional autonomy. ${ }^{19}$ Both researchers focus on the principle of regional autonomy, not overlapping regulations in land acquisition. Meanwhile, Yusrizal researched aspects of legal protection for land rights holders in land acquisition for the public interest. ${ }^{20}$ Some of these researches are used as references and find gaps and novelties in this research.

Based on this background, the focus of this paper discusses the legal analysis of indemnity arrangements in the procurement of land for development for the public interest, more explicitly governing the: determination of Land Assessors (Assessors); indemnity assessment; Deliberation on the determination of indemnity; and contingency indemnity in the District Court.

\section{RESEARCH METHODS}

This research uses a doctrinal juridical approach. ${ }^{21}$ The type of data used is secondary data, sourced from primary and secondary legal materials. ${ }^{22}$ The approach method used in this research is the case and comparison approach. ${ }^{23}$ Laws and regulations governing land, land acquisition, consignment and human rights use as primary data sources. At the same time, secondary data was collected from journals, reference books, academic texts, articles, research results, and printed and electronic media news. ${ }^{24}$ Data collection techniques are done by searching libraries and documents both physically and electronically. Subsequently, the data obtained were analyzed using content analysis and prescriptive analysis. ${ }^{25}$

19 Hardianto Djanggih and Salle Salle, 'Aspek Hukum Pengadaan Tanah Bagi Pelaksanaan Pembangunan Untuk Kepentingan Umum', Pandecta: Jurnal Penelitian Ilmu Hukum (Research Law Journal), 12.2 (2017), 165-72 <https://doi.org/10.15294/pandecta.v12i2.11677>.

20 Muhammad Yusrizal, 'Perlindungan Hukum Pemegang Hak Atas Tanah Dalam Pengadaan Tanah Untuk Kepentingan Umum', De Lega Lata, 2.1 (2017), 113-38.

${ }^{21}$ Fifik Wiryani, Mokhammad Najih, and Abdul Haris, 'Juridical Analysis On Consumer Protection In Safe and Halal', Dinamika Hukum, 18.1 (2018), 20-29 <https://doi.org/http://dx.doi.org/10.20884/1.jdh.2018.18.1.1586>.

22 Peter Mahmud Marzuki, Penelitian Hukum (Jakarta: Kencana Prenada Media Group, 2014).

23 Irwansyah, Penelitian Hukum Pilihan Metode \& Praktik Penulisan Artikel, ed. by Ahsan Yunus, 1st edn (Yogyakarta: Mitra Buana Media, 2020).

24 Johnny Ibrahim, Teori Dan Metodologi Penelitian Hukum Normatif (Malang: Bayumedia, 2007).

25 Tata Wijayanta, 'Asas Kepastian Hukum, Keadilan Dan Kemanfaatan Dalam Kaitannya Dengan Putusan Kepailitan Pengadilan Niaga', Jurnal Dinamika Hukum, $14.2 \quad$ (2014) <http://dx.doi.org/10.20884/1.jdh.2014.14.2.291>. 


\section{ANALYSIS AND DISCUSSION}

\section{Deliberation of Compensation on Land Acquisition for Public Interest}

Deliberation on the determination of compensation is regulated in Article 37 to Article 39 of the Land Procurement Law. Provisions on deliberation are implementing humanitarian and democratic principles, the principle of justice, the principle of certainty, and the principle of agreement. Deliberations are conducted between the Land Institution and the Entitled Party within a period of not later than 30 working days from submitting the indemnity assessment by the Assessor to the Land Institution. The purpose of deliberation is to obtain the results of an agreement on the form and/or amount of compensation and the determination and awarding of compensation to the Rightful Party.

The Land Procurement Act and its implementing regulations do not expressly define the word "deliberation". The definition of "deliberation" is juridically found only in Article 1 (10) of Presidential Regulation No. 36 of 2005, namely "activities containing the process of hearing each other, giving and receiving opinions to each other, as well as the desire to reach an agreement on the form and amount of compensation and other issues related to land procurement activities based on volunteerism and equality between parties who own land, buildings, plants, and other objects related to land with parties requiring land." Deliberation is a more efficient way to reach a win-win solution. ${ }^{26}$

Hanafi stated that the essence of deliberation is a manifestation of the reality of equality of human position and kingdom, freedom of speech, the right to criticize and the recognition of humanity. ${ }^{27}$ Kuntowijoyo, in his prophetic theory, stated that it is necessary to have humanization, liberation and transcendence in deliberation. Humanization is interpreted as an attitude always to humanize people. Liberation means the nation's liberation from the cruelty of poverty, the hubris of technology and the extortion of abundance. While in transcendence, it is necessary to add a transcendent dimension (godhead) in culture, in human nature that is to restore this world as a mercy to all creation (rahmatan lil 'alamin). ${ }^{28}$ maqasid as-syar'iyah, which creates benefit for all people. $^{29}$

Based on the basic meaning of the agreement and the understanding of the deliberation, it can be understood that there is deliberation if in the process meets the elements: 1) The equal position of the Parties; 2) Based on the Willingness of the Parties; 3) The Parties have the intention, desire and result in an agreement or consensus; 4) Conducted in the process of listening to each other, giving each other and accepting each other's opinions; 5) there is no element of coercion; and 6) contains transcendent elements to realize rahmatan lil 'alamin The result of the deliberation agreement, made in the news of the agreement signed by the Parties present, both those who

26 Yesi Eka Pratiwi and Sunarso Sunarso, 'Peranan Musyawarah Mufakat (Bubalah) Dalam Membentuk Iklim Akademik Positif Di Prodi Ppkn Fkip Unila', Sosiohumaniora, $20.3 \quad$ (2018), 199 $<$ https://doi.org/10.24198/sosiohumaniora.v20i3.16254>.

27 Muhammad Hanafi, 'Kedudukan Musyawarah Dan Demokrasi Di Indonesia', Jurnal Cita Hukum, 1.2 (2016) <https://doi.org/10.15408/jch.v1i2.2657>.

28 Tsalis Rifa'i, 'Komunikasi Dalam Musyawarah (Tinjauan Konsep Asyura Dalam Islam)', CHANNEL Jurnal Komunikasi, 3.1 (2015), 36-45 <https://doi.org/10.12928/channel.v3i1.2412〉.

29 Irfan Papalia, 'Konsep Musyawarah Dan Ganti Rugi Dalam Pengadaan Tanah Untuk Kepentingan Umum Prespektif Hukum Islam', Jurnal Lex Renaissance, $3.1 \quad$ (2018), 171-88 <https://doi.org/10.20885/jlr.vol3.iss1.art7>. 
agreed to the results of the deliberations and who rejected it. The news of the event is then used as the basis for providing compensation to the Entitled Party.

As for parties who do not agree to the agreement, they are allowed to submit objections to the District Court (PN) within 14 working days after deliberation. If the decision of the PN is deemed to have not provided justice, the Rightful Party can proceed with the application for Cassation to the Supreme Court (MA) within 14 working days of the decision of the PN. The verdict of PN / MA has been inkracht as the basis in the provision of compensation. So, the Entitled Party receives compensation based on the result of the agreement in the deliberations/decisions of judges who are already inkracht.

The arrangement of deliberation on the determination of compensation in Article 37 paragraph (1) and Article 39 of the Land Procurement Law is inconsistent with the principles and principles used as guidelines or guidelines in formulating land procurement norms. Inconsistencies in Article 37 paragraph (1) of the Land Procurement Law, specifically contained in the sentence: 1) "The Land Institution conducts deliberations with the Entitled Party within a maximum of 30 (thirty) working days since the assessment results from the Assessor are submitted to the Land Institution"; and 2) "the form and/or amount of indemnity based on the results of the indemnity assessment as referred to in Article 34."

Deliberation on the form and amount of compensation, especially to the land for the owner, is a very urgent activity because it can affect their lives after land procurement, especially for the owner who relies on his life and livelihood on the land owned. So that in the implementation of deliberation must consider the elements and essence of deliberation. Time restriction on the sentence "Land Institution conducts deliberation with the Rightful Party within a maximum of 30 (thirty) working days since the assessment results from the Assessor submitted to the Land Institution", has reduced the essence of deliberation because of the potential implementation of deliberation procedurally to abort the obligation only, thereby ignoring the essence and elements of deliberation. In addition, the Land Procurement Law does not regulate the provision of access to information on the manner, and basis of compensation assessments carried out by assessors and information on when the Assessor submits the results of its assessment to the Land Agency.

Inconsistent with the principle of openness because in the law on land procurement, there is no norm that regulates the provision of access to information on the way and basis of compensation assessment conducted by the Assessor and information on when the Assessor submits the results of his assessment to the Land Agency. Inconsistencies in the arrangement between the principle of openness and the unregulated norms of access to information on the assessment of land procurement objects and the grace period of submission of the assessment from the Assessor to the Land Institution, resulting in the blurring of legal certainty, and further implying the unfulfilled principle of justice, namely providing a guarantee of proper reimbursement to the Entitled Party in the Land Procurement process, thereby providing opportunities for the Entitled Party to be able to carry out a better life. In addition, there is also no certainty in realizing the principle of welfare, which can provide added value for the survival of the Entitled Party and society at large. In the end, the purpose of the Land Procurement Law in Article 3, namely to improve the welfare and prosperity of the nation, state, and society while ensuring the legal interests of the Entitled Party, is threatened to fail to be realized. 
As for the sentence "form and/or amount of indemnity based on the result of indemnity assessment as referred to in Article 34," assuming the Right Party objects at all stages of activities, then the time required from the announcement of location determination up to the awarding of compensation is at the maximum 354 working days or approximately 455 calendar days. The length of the grace period implies a very high increase in land prices, as the results of previous research discussed in Sub C.1.b.

The establishment of good regulation should be based on the principle of formal and material law. The principle of law provides the required direction, namely guiding how and in which direction the regulation will be developed, so that the purpose of the formation of the regulation can be achieved. One of the principles of formal law is the principle of clear purpose. The purpose of the Land Procurement Law is contained in Article 3, namely to provide land for the implementation of development in order to improve the welfare and prosperity of the nation, state and society while ensuring the interests of the appropriate legal parties.

Land ownership is a constitutional right and human right protected by Article $28 \mathrm{G}$ paragraph (1) and Article $28 \mathrm{H}$ paragraph (4) of the 1945 Constitution. So normatively, unilateral claims by the State in Article 39 are contrary to the values of Pancasila, Article 28 G paragraph (1) and Article $28 \mathrm{H}$ paragraph (4) of the 1945 Constitution, the General Declaration of Human Rights Article 17.1, Article 17.2 and Article 30 that Indonesia has ratified. Problems in the norm of Article 39 because it regulates the legal consequences of the Entitled Party who in deliberation rejects the form and/or amount of indemnity, but does not file an objection within the specified time, then because the law in question is considered to accept the form and amount of indemnity based on the assessment of the Assessor.

Article 39 of the Land Procurement Law is contradictory, on the one hand, the law formulates that the Entitled Party has manifestly rejected the form and/or amount of compensation. However, on the other hand, the Land Procurement Law stipulates for the sake of the relevant law is considered to receive compensation based on the assessment results of the Assessor who has been expressly rejected by the Rightful Party. The provision of Article 39 shows the arrogance of lawmakers who claim that the state's position is higher than the position of the people as landowners. Based on the principle of State Control Rights in Article 33 of the 1945 Constitution, the state is only an organ mandated by the People of Indonesia to realize the welfare of the people through development.

The country claims to be a form of forced seizure of people's land. In the Basic Agrarian Law perspective, the claim in Article 39 of the Land Procurement Law is not a way of removing land rights. So, the right to the land still belongs to the Entitled Party. Philosophically, the provisions of Article 39 of the Land Procurement Law are not in line with the principle of legal certainty, the principle of justice and the principle of welfare. Based on the principle of lex superior derogat legi inferior, legislation at a higher level overrides the legislation at a lower level. Article 39 of the Land Procurement Law has been contrary to Article 28 G paragraph (1) and Article $28 \mathrm{H}$ paragraph (4) of the 1945 Constitution. So that juridically Article 28 G paragraph (1) and Article $28 \mathrm{H}$ paragraph (4) of the 1945 Constitution override the provisions of Article 39 of the Land Procurement Law.

An alternative formulation of Article 37 paragraph (1) turns into "The Land Institution conducts deliberations with the Entitled Party to establish the form and/or amount of compensation 
that is feasible based on the result of the agreement to guarantee to the Entitled Party can carry out a better life"

As an effort to realize the objectives of the Land Procurement Law and synchronize the principles and principles that become its guidelines and to provide legal certainty and ensure the consistency of the implementation of the Procurement Law, the alternative actions that need to be taken are: 1) the House of Representatives Repeals Article 39; 2) The Entitled Party whose constitutional rights are violated submits an application for the material test of Article 39 to the Constitutional Court; 3) Amend the formulation of the norms of Article 39 to "In the case that the Entitled Party rejects the form and/or amount of damages in deliberation, for the public interest the right to land is revoked, and the Entitled Party is awarded proper damages under the HBU Principle"; or 4) Applying the principle of lex superior derogat legi inferior in the implementation of land procurement for the public interest.

Inconsistencies in the provisions on the deliberation of the determination of compensation, implying the implementation of the regulation becomes ineffective and inefficient, resulting in the absence of certainty of law, justice and benefit, especially for landowners. Deliberation should be as a way of finding a middle way in determining the amount of compensation, but at the level of implementation often in deliberation is not reached an agreement so that the Committee/Organizer of Land Procurement then unilaterally determine the amount of compensation based on the results of the assessment and do not provide alternative other options, under the pretext of the public interest. $^{30}$

The fact is, among others, in the case of land acquisition for flooding east canals in Jakarta, the Land Procurement Committee confirmed the terms of the compensation deliberation, by only making a one-time compensation offer, without dialogue, no process of hearing each other, giving and receiving opinions, and not producing an agreement. ${ }^{31}$ unilateral pricing and unfair enforcement, starting price coercion, breaking up the concentration of landowners, snitching, intimidation and terror. There is no clarity on the details of the indemnity object, classification and unit price. ${ }^{32}$ was also found in the procurement of land to construct the Trans Java Toll Road in Tegal Regency on Sustainable Food Agricultural Land. ${ }^{33}$

Furthermore, the Committee entrusted the damages to the local District Court through a contingency mechanism. ${ }^{34}$ the construction of West Java International Airport (BIJB) and New Yog-

30 Fifik Wiryani and Nurhasan Ismail, 'Penerapan Prinsip Partisipatif Dan Keadilan Sosial Dalam Pengaturan Dan Pelaksanaan Pengadaan Tanah Bagi Pembangunan Untuk Kepentingan Umum’ (Universitas Gadjah Mada, 2016).; Rizky Amalia, 'Perlindungan Hukum Bagi Pemegang Hak Atas Tanah Dalam Penetapan Ganti Rugi Terkait Dengan Pengadaan Tanah Untuk Kepentingan Umum', Yuridika, 27.3 (2012), 267-80.; Septia Putri Riko, 'Pelaksanaan Pengadaan Tanah Untuk Kepentingan Umum Dalam Hubungannya Dengan Perlindungan Lahan Pertanian Pangan Berkelanjutan (Studi Pada Pembangunan Jalan Tol Trans Jawa Di Kabupaten Tegal)' (Universitas Dioinegoro, 2010).

31 Djoni Sumardi Gozali, 'Penerapan Asas Kesepakatan Dalam Pengadaan Tanah Bagi Pembangunan Untuk Kepentingan Umum', Yuridika, 32.3 (2017), 393-414 <https://doi.org/10.20473/ydk.v32i3.4783>.

32 Gozali.

33 Riko.

34 Mia Mentari Faroya, Suharnoko, and Endah Hartati, 'Perbandingan Lembaga Konsinyasi Sebagai Cara Menghapuskan Perikatan Dan Lembaga Konsinyasi Dalam Pengadaan Tanah Bagi Pembangunan Untuk Kepentingan Umum', 2013. 
yakarta International Airport (NYIA), ${ }^{35}$ land acquisition for the construction of power plants in West Lombok. ${ }^{36}$ process of land acquisition for Karalloe Dam, LBH Makassar informs that the deliberation process is not conducted openly. The Entitled Party must accept the offer of compensation based on the assessment of the Assessor and not be given the opportunity to reject it. Against the act of refusing to compensate in deliberation resulted in the stigmatization/labelling of the PKI, and criminal proceedings were carried out with the allegations made up. ${ }^{37}$

The majority of the Committee or Land Procurement Organizers in carrying out deliberations position higher than the Right Parties, so that the implementation of deliberation seems a formality, by only conducting deliberations once, in the same direction, offering compensation based on the results of the assessment without giving alternative ${ }^{38}\left({ }^{39} \mathrm{Amalia}, 2012\right)$ The situation can also be a form of indirect warning to the owner not to ask for a price that is too high, and without considering the wishes of the Entitled Party to get proper compensation so that the legal protection for land rights holders in land procurement is deficient. ${ }^{40}$ The Committee feels not authorized to offer prices above appraisal estimated value. The implementation of the deliberations shows the absence of a process of hearing each other, giving and receiving each other opinions in deliberations, the absence of intention to produce an agreement. ${ }^{41}$ Banjarbaru, the widening of the road on Jalan Veteran Banjarmasin, ${ }^{42}$ of the value of compensation, ${ }^{43}$ even in the construction of hydropower plants in West Lombok, there is discrimination in the determination of compensation for land that has been certified with uncertified, as well as the absence of compensation for the use of Pecatu land, which is customary land of local indigenous peoples. ${ }^{44}$ in the morning, with the involvement of security apparat. Furthermore, with the threat of weapons, the public is forced to sign without knowing the signed contents. For those who do not want to sign or run, then the compensation money is given.

The success story of indemnity deliberation was found in the land acquisition process for the construction of NYIA Yogyakarta Airport in Kulonprogo, which offers various forms of compensation. At the beginning of the deliberations, many people applied for relocation but, after seeing the high amount of compensation value, then asked for a change in the form of compensation to money. In addition, the Kulonprogo Local Government provides accessible housing facilities to affected residents who have households, namely staying with the elderly or owning a house but the land belongs to someone else.

35 Agus Suntoro, 'Penilaian Ganti Kerugian Dalam Pengadaan Tanah Untuk Kepentingan Umum : Perspektif Ham Assessment of Compensation in Land Acquisition for Public Interest: Human Rights Perspective *', BHUMI: Jurnal Agraria Dan Pertanahan, 5.1 (2019), 13=25 <https://doi.org/http://dx.doi.org/10.31292/jb.v5i1.316 Copyright:>.

36 Basri.

37 M. Choirul Anam, Amiruddin Al Rahab, and Agus Suntoro, Kajian Terhadap UU Nomor 2 Tahun 2012 Tentang Pengadaan Tanah Bagi Pembangunan Untuk Kepentingan Umum (KOMNAS HAM, 2018).

38 Wiryani and Ismail.

39 Amalia.

40 Basri.

41 Wiryani and Ismail.

42 Gozali.

43 Evi Fajriantina Lova and others, Pengadaan Tanah Dalam Pembangunan Infrastruktur Jalan Tol Oleh Badan Usaha Milik Negara (Persero).

44 Basri. 
Based on the results of the discussion on the arrangement of deliberation on the determination of compensation as stipulated in Article 37 paragraph (1), then in order to realize the harmonization of the law, the alternative reformulation of the article becomes "Land Institution together with the Rightful Party in the same position and deliberately conduct deliberation to obtain the results of the agreement on the form and/or amount of compensation worthy under the HBU Principle."

\section{Compensation Analysis for Land Acquisition}

Contingency is one way of removing the alliance based on Article 1381 of the Civil Code. Article 1381 confirms that the contingency is carried out if there has previously been a legal relationship under Article 1320 of the Civil Code. Contingency mechanism on land procurement for the public interest, adopting the concept of contingency stipulated in book III Civil Code on the Alliance Article 1404 - Article 1412. Condition or deposition of money is defined as the offer of payment in cash by the debtor who is in good faith to the default creditor (mora kreditoris) ${ }^{45}$ not known to exist, followed by storage or custody. This contingency is usually carried out within the time leading up to the expiration of the alliance after all debts or obligations are fulfilled. ${ }^{46}$

The regulation of contingency norms in Article 42 paragraph (1) and Article 43, according to the author is incorrect, because in Article 42 paragraph (1), the rejection of the results of deliberation by the Entitled Party means that there is no agreement between the institution that requires the land and the Rightful Party as the owner of the land. The absence of an agreement which is a condition of legal relations under Article 1320 of the Civil Code, implies the absence of a legal relationship between the Parties. No legal relationship means no rights and obligations to the Parties. Thus, the juridical right to land remains the property of the Entitled Party, which is a constitutional and human rights right for the owner.

The solution that should be done is through the mechanism of revocation of land rights based on the 1945 Constitution Article 28G paragraph (1), Article 28H paragraph (4), Article 28J paragraph (1); TAP MPR No. XVII/MPR/1998 on Human Rights Article 32UU HAM Article 36 paragraphs (1) and (2); Agrarian Basic Law Article 18, Article 27.a.1, Article 34.d, and Article 40.d; and Law 20 of 1961 on the Revocation of Land Rights and Objects there. These conditions will be different if, in the end, the Right Party voluntarily or forced to take compensation for the losses that are consist in the PN. The claim for compensation that is consistent can be said that the person concerned for the sake of the law is considered to agree to accept compensation as a price for the release of his land rights.

The provisions of Article 42 paragraph (1) and Article 43 of the Land Procurement Law can be enforced if the Rightful Party rejects the results of deliberation, whether the objection or does not object or reject the decision of the PN/MA that has been inkracht, but then for various reasons voluntarily or forced to take the compensation money that is concurred, then the Rightful Party is considered to secretly agree to accept the compensation that is concurred as well as relinquish the right to land. ${ }^{47}$ As for the Owner/Party entitled to the land that does not take the money indemnity

45 Suntoro.

46 Florentina Rosalin Kusumarini, Ana Silviana, and Triyono, 'Diponegoro Law Journal', Diponegoro Law Journal, 5.6 (2016), 1-13.

47 Maria S.W. Sumardjono, Dinamika Pengaturan Pengadaan Tanah Di Indonesia Dari Keputusan Presiden Sampai Undang-Undang, ed. by Siti, Pertama (Yogyakarta: Gadjah Mada University Press, 2015). 
that is presented in the PN, does not relinquish the rights to the land and still controls the evidence of land ownership and/or physical control of the land, then juridically the land remains his which is a constitutional and human rights right.

The regulation of Article 42 concerning contingency conducted if the RightFul Party refuses to accept compensation based on the results of deliberations or decisions of the PN/MA that has been inkracht, according to the author, is incorrect. The consideration is to adopt the contingency provisions of the KUHPerdata, that the contingency is carried out if preceded by an agreement that occurs based on an agreement. While the contingency on land procurement, which is not based on the results of the agreement in deliberation, results in the absence of a legal relationship between the landowner and the State (agencies that require land). Thus, It is a more appropriate way out of the problem to perform a mechanism for revoking land rights based on the law on the Revocation of Land Rights.

Contingency mechanism can be done to the Party entitled to receive compensation is not known to exist and/or the object of land procurement to be given indemnity is the object of the court case; still disputed ownership; confiscated by authorized officials; or be a guarantee at the bank. The result of the deliberation agreement, made in the news of the agreement signed by the Parties present, both those who agreed to the results of the deliberations and those who rejected it. The news of the event is then used as the basis for providing compensation to the Entitled Party.

As parties who do not agree to the agreement can then submit an objection to the District Court (PN) within 14 working days after deliberation. If the decision of the PN is deemed to have not provided justice, the Rightful Party can proceed with the application for Cassation to the Supreme Court (MA) within 14 working days of the decision of the PN. The verdict of PN/MA has been inkracht as the basis in the provision of compensation. So, the Entitled Party receives compensation directly based on the assessment results set out in the deliberations/decisions of judges who are already inkracht. The awarding of compensation is done in conjunction with the waiver of land rights and the submission of evidence of ownership or ownership of the land. If the rights holder refuses to accept the compensation offered in deliberations or decisions of the PN/MA judge, then the damages are deposited in the local PN. Indemnity claims which is rejected by the Entitled Party is a unilateral action, as if an agreement has been made to receive compensation and the responsibility to pay compensation is deemed to have been carried out. Indemnity storage is considered as giving legitimacy to agencies that require land to begin physical activities of development.

For The Right Party who refuses compensation based on the result of deliberation agreement or judge's ruling that is already inkracht, then the compensation is deposited to the local PN. Indemnity to the PN is called contingency terms. Article 43 of the Land Procurement Act states that "at the time of the implementation of the awarding of compensation and waiver of land rights or the granting of compensation has been deposited in the PN, then the ownership of land rights of the Entitled Party becomes removed and the evidence of its rights is declared invalid and the land becomes land controlled directly by the state". The formulation of the norms of Article 43 of the Law is expressly and clearly a form of deprivation of people's land by the state.

At the contingency conducted on the grounds: a) The Rightful Party refuses to accept compensation based on the results of deliberations or decisions PN/MA that has been inkracht; and b) The Party entitled to receive damages is not known existence, the sentence "the provision of com- 
pensation has been deposited in the PN, then the ownership of land owned by the Rightful Party to be removed, the evidence of its rights declared invalid, and the land becomes land controlled directly by the state" in Article 43 of the Land Procurement Act is not appropriate, especially against the attitude of landowners who do not take compensation money that is consist, do not relinquish the right to land and still maintain to control the land. Because the sentence can be interpreted as the deprivation of land ownership, which is a constitutional right as well as human rights protected by Article $28 \mathrm{G}$ paragraph (1) and Article $28 \mathrm{H}$ paragraph (4) of the 1945 Constitution, juridically, the land is still the property of the concerned. Article 43 is contrary to the principle of "The principle of lex superior derogate legi inferior."

In addition, the provisions of Article 43 of the Land Procurement Law are also inconsistent with almost all principles in the Land Procurement Law, namely the principles: humanity, justice, benefit, certainty, agreement, welfare, sustainability and the principle of harmony. Those principles were taken by India government on their law, ${ }^{48}$ especially on land acquisition topics. In addition, Article 43 is also contrary to the provisions on the removal of land rights stipulated in Article 27, Article 34, and Article 40 of the Agrarian Basic Law. So based on the principle of lex superior derogate legi inferior, Article 43 of the Land Procurement Act must be ruled out because it is contrary to the Constitution.

To align the provisions of Article 43 with the principles in the Land Procurement Law, the formulation of Article 43 needs to be changed to: "At the time of the implementation of the awarding of Indemnity and Waiver as referred to in Article 41 paragraph (2) letter a has been implemented ownership or Land Rights of the Rightful Party to be removed, and the evidence of its rights declared invalid and the land becomes land controlled directly by the state". Those changes guarantee the landowners to get their rights properly, get proper compensation at a fair price and be protected by the law. ${ }^{49}$

\section{CONCLUSION}

Based on the results of the discussion that has been done in the previous subchapter, the conclusion is drawn as follows: arrangement of compensation in land procurement for the development of public interest in the Land Procurement Law there are still inconsistencies between the principles of land procurement that should be used as the basis and guidelines for the formulation of norms regulated in it. Regulation of indemnity norms that are inconsistent with their principles, especially the material regarding the Assessor's determination, the value of indemnity, deliberation of the determination of indemnity, and the custody of indemnity in the District Court (consignment).

Article 31 paragraph (1) of the Land Law regulates that the determination of assessors is carried out unilaterally by the Land Agency, which doubles as a government agency in the field of land concurrently as the executor of land procurement. The norm can reduce the independence of assessors who are prone to intervention from the Land Institute. The arrangement of the value of compensation is the value at the time of the announcement of the determination of the construc-

48 Sanjoy Chakravorty, 'Land Acquisition in India: The Political-Economy of Changing the Law', Area Development and Policy, 1.1 (2016) <https://doi.org/https://doi.org/10.1080/23792949.2016.1160325>.

49 Anuar Alias and M D Nasir Daud, 'Payment of Adequate Compensation for Land Acquisition in Malaysia', Pacific Rim Property Research Journal, $12.3 \quad$ (2006) <https://doi.org/https://doi.org/ 10.1080/14445921.2006.11104213>. 
tion site stipulated in Article 34 paragraph (1) has the potential to reduce the welfare level of the Entitled Party significantly due to the surge in land prices. Assuming that at each activity there are objections, then the period between location determination to compensation is 354 working days equivalent to 455 calendar days ( \pm one year three months).

The limitation of the implementation of deliberations for a maximum of 30 working days since the Assessor submits the results of his assessment to the Land Institution in Article 37 paragraph (1) reduces the essence of deliberation and potentially the implementation of formality deliberation to abort the obligation only, not substantive to produce a win-win solution agreement. The seriousness of the deliberation arrangements is also seen in Article 39, which rejects the damages offered by the Land Agency but does not object to accepting the compensation offered. The provision of Article 39 is a form of forced seizure of land covertly. The formulation of contingency norms indemnity adopting Civil Code in Article 42 paragraph (1) and Article 43 is incorrect because rejection means there is no agreement in deliberation, so it does not create relationships. No legal relationship means no rights and obligations to the Parties. The legal implication is that the right to land remains the property of the Entitled Party, which is a constitutional and human rights right for the owner.

\section{REFERENCES}

Adhim, Nur, 'Model Upaya Hukum Terhadap Ganti Kerugian Dalam Pengadaan Tanah Untuk Kepentingan Umum (Studi Kasus Pembangunan Jalan Tambaklorok, Kota Semarang)', Gema Keadilan, 6.1 (2019), 75 <https://doi.org/10.14710/gk.6.1.75-85>

Alias, Anuar, and M D Nasir Daud, 'Payment of Adequate Compensation for Land Acquisition in Malaysia', Pacific Rim Property Research Journal, 12.3

(2006) <https://doi.org/https://doi.org/10.1080/14445921.2006.11104213>

Amalia, Rizky, 'Perlindungan Hukum Bagi Pemegang Hak Atas Tanah Dalam Penetapan Ganti Rugi Terkait Dengan Pengadaan Tanah Untuk Kepentingan Umum', Yuridika, 27.3 (2012), 267-80

Anggraeny, Isdian, and Sholahuddin Al-Fatih, 'Kata Sepakat Dalam Perjanjian Dan Relevansinya Sebagai Upaya Pencegahan Wanprestasi', De Lega Lata: Jurnal Ilmu Hukum, 5.1 (2020), 57-66 <https://doi.org/10.30596/dll.v5i1.3446>

Atmaja, Harry Kurniadi, and Kasyful Mahalli, 'Pengaruh Peningkatan Infrastruktur Terhadap Pertumbuhan Ekonomi Di Kota Sibolga', Jurnal Ekonomi, 3.4, 248-66

Bahar, Ujang, 'Permasalahan Pembayaran Ganti Rugi Pengadaan Tanah Bagi Pelaksanaan Pembangunan Untuk Kepentingan Umum', Jurnal Hukum \& Pembangunan, 38.1 (2008), 122 <https://doi.org/10.21143/jhp.vol38.no1.166>

Basri, Hasan, 'Keadilan Dan Kepastian Hukum Bagi Pemegang Hak Atas Tanah Dalam Pengadaan Tanah Untuk Kepentingan Umum', IUS Kajian Hukum Dan Keadilan, 1.1 (2013), 77-93

Chakravorty, Sanjoy, 'Land Acquisition in India: The Political-Economy of Changing the Law', $\begin{array}{lllll}\text { Area Development } & \text { and } & \text { Policy, } & 1.1 & \text { (2016) }\end{array}$ <https://doi.org/https://doi.org/10.1080/23792949.2016.1160325>

'Direktori Putusan Mahkamah Agung Republik Indonesia'

Djanggih, Hardianto, and Salle Salle, 'Aspek Hukum Pengadaan Tanah Bagi Pelaksanaan 
Pembangunan Untuk Kepentingan Umum', Pandecta: Jurnal Penelitian Ilmu Hukum $\begin{array}{lllll}\text { (Research Law } & \text { Journal), } & 12.2 & \text { (2017), }\end{array}$ <https://doi.org/10.15294/pandecta.v12i2.11677>

Erwin, Muhamad, 'Reconstruction the Paradigm of Law and Justice on the Regulation of Right to Living Space of the Orang Rimba Tribe in Bukit Duabelas, Jambi Province', Sriwijaya Law Review, 2.1 (2018), 56 <https://doi.org/10.28946/slrev.vol2.iss1.110.pp56-68>

Fajriantina Lova, Evi, Moh Fadli, Hariyanto Susilo, Program Studi, and Magister Kenotariatan, Pengadaan Tanah Dalam Pembangunan Infrastruktur Jalan Tol Oleh Badan Usaha Milik Negara (Persero)

Faroya, Mia Mentari, Suharnoko, and Endah Hartati, 'Perbandingan Lembaga Konsinyasi Sebagai Cara Menghapuskan Perikatan Dan Lembaga Konsinyasi Dalam Pengadaan Tanah Bagi Pembangunan Untuk Kepentingan Umum', 2013

Gozali, Djoni Sumardi, 'Penerapan Asas Kesepakatan Dalam Pengadaan Tanah Bagi Pembangunan Untuk Kepentingan Umum', Yuridika, 32.3 (2017), 393-414 <https://doi.org/10.20473/ydk.v32i3.4783>

Hanafi, Muhammad, 'Kedudukan Musyawarah Dan Demokrasi Di Indonesia', Jurnal Cita Hukum, 1.2 (2016) <https://doi.org/10.15408/jch.v1i2.2657>

Irwansyah, Penelitian Hukum Pilihan Metode \& Praktik Penulisan Artikel, ed. by Ahsan Yunus, 1st edn (Yogyakarta: Mitra Buana Media, 2020)

Jade, Adinda Putri, Diah Nadia Putri, and Sholahuddin Al-Fatih, 'Perizinan Membuka Tanah Negara Di Kota Balikpapan', Supremasi Hukum: Jurnal Penelitian Hukum, 29.2 (2020), 102-30 <https://doi.org/https://doi.org/10.33369/jsh.29.2.\%25p>

Johnny Ibrahim, Teori Dan Metodologi Penelitian Hukum Normatif (Malang: Bayumedia, 2007)

'Jokowi Bangun 3.432 Km Jalan Nasional Dan 941 Km Jalan Tol'

Kasenda, Dekie GG, 'Ganti Rugi Dalam Pengadaan Tanah Untuk Kepentingan Umum', Jurnal Morality, 2.2 (2015), 1-21

Keusuma, Cut Nanda, and Suriani Suriani, 'Pengaruh Pembangunan Infrastruktur Dasar Terhadap Pertumbuhan Ekonomi Di Indonesia', ECOsains: Jurnal Ilmiah Ekonomi Dan Pembangunan, 4.1 (2015), 1-18

Kusumarini, Florentina Rosalin, Ana Silviana, and Triyono, 'Diponegoro Law Journal', Diponegoro Law Journal, 5.6 (2016), 1-13

M. Choirul Anam, Amiruddin Al Rahab, and Agus Suntoro, Kajian Terhadap UU Nomor 2 Tahun 2012 Tentang Pengadaan Tanah Bagi Pembangunan Untuk Kepentingan Umum (KOMNAS HAM, 2018)

Manoe, Sumral Buru, 'Konstruksi Hak Menguasai Negara Dalam Tata Laksana Pengadaan Tanah Bagi Kepentingan Umum Di Kabupaten Semarang', I.2 (2014), 228-36

Maryaningsih, Novi, Oki Hermansyah, and Myrnawati Savitri, 'Pengaruh Infrastruktur Terhadap Pertumbuhan Ekonomi Indonesia', Buletin Ekonomi Moneter Dan Perbankan, 17.1 (2014), 61-98

Mustafa, Marni Emmy, 'Penawaran Pembayaran Tunai Dan Konsignasi Di Pengadilan Untuk Pengadaan Tanah Bagi Pembangunan Untuk Kepentingan Umum’, 2019, pp. 1-17

Papalia, Irfan, 'Konsep Musyawarah Dan Ganti Rugi Dalam Pengadaan Tanah Untuk 
Kepentingan Umum Prespektif Hukum Islam', Jurnal Lex Renaissance, 3.1 (2018), 171-88 <https://doi.org/10.20885/jlr.vol3.iss1.art7>

Peter Mahmud Marzuki, Penelitian Hukum (Jakarta: Kencana Prenada Media Group, 2014)

Pratiwi, Yesi Eka, and Sunarso Sunarso, 'Peranan Musyawarah Mufakat (Bubalah) Dalam Membentuk Iklim Akademik Positif Di Prodi Ppkn Fkip Unila', Sosiohumaniora, 20.3 (2018), 199 <https://doi.org/10.24198/sosiohumaniora.v20i3.16254>

Presiden RI, Peraturan Presiden Nomor 71 Tahun 2012 Tentang Penyelenggaraan Pengadaan Tanah Bagi Pembangunan Untuk Kepentingan Umum (Indonesia: Lembaran Negara Republik Indonesia Tahun 2012 Nomor 156, 2012)

Rifa'i, Tsalis, 'Komunikasi Dalam Musyawarah (Tinjauan Konsep Asyura Dalam Islam)', $\begin{array}{lllll}\text { CHANNEL Jurnal } & \text { Komunikasi, } & 3.1 & \text { (2015), }\end{array}$ <https://doi.org/10.12928/channel.v3i1.2412>

Riko, Septia Putri, 'Pelaksanaan Pengadaan Tanah Untuk Kepentingan Umum Dalam Hubungannya Dengan Perlindungan Lahan Pertanian Pangan Berkelanjutan (Studi Pada Pembangunan Jalan Tol Trans Jawa Di Kabupaten Tegal)' (Universitas Dioinegoro, 2010)

Rusli, Tami, 'Analisis Pelaksanaan Konsinyasi Ganti Rugi Pada Pengadaan Tanah', Keadilan Progresif, 9.1 (2018), 15-28

Santoso, Urip, 'Penyelesaian Sengketa Dalam Pengadaan Tanah Untuk Kepentingan Umum', Perspektif, 21.3 (2016), 188-98

Sinilele, Ashar, 'Tinjauan Yuridis Terhadap Pelaksanaan Pengadaan Tanah Bagi Pembangunan Untuk Kepentingan Umum Di Kota Makassar', Jurnal Al-Qadau, 4.1 (2017), 1-24

Soleman, Mochdar, and Mohammad Noer, 'Nawacita Sebagai Strategi Khusus Jokowi Periode Oktober 2014-20 Oktober 2015', Jurnal Kajian Politik Dan Masalah Pembangunan, 13.1 (2017), 1961-75

Subekti, Rahayu, 'Kebijakan Pemberian Ganti Kerugian Dalam Pengadaan Tanah Bagi Pembangunan Untuk Kepentingan Umum', Yustisia, 5.2 (2016), 376-94

Sumardjono, Maria S.W., Dinamika Pengaturan Pengadaan Tanah Di Indonesia Dari Keputusan Presiden Sampai Undang-Undang, ed. by Siti, Pertama (Yogyakarta: Gadjah Mada University Press, 2015)

Suntoro, Agus, 'Penilaian Ganti Kerugian Dalam Pengadaan Tanah Untuk Kepentingan Umum : Perspektif Ham Assessment of Compensation in Land Acquisition for Public Interest: Human Rights Perspective *', BHUMI: Jurnal Agraria Dan Pertanahan, 5.1 (2019), 13=25 <https://doi.org/http://dx.doi.org/10.31292/jb.v5i1.316 Copyright:>

Wijayanta, Tata, 'Asas Kepastian Hukum, Keadilan Dan Kemanfaatan Dalam Kaitannya Dengan Putusan Kepailitan Pengadilan Niaga', Jurnal Dinamika Hukum, 14.2 (2014) <http://dx.doi.org/10.20884/1.jdh.2014.14.2.291>

Wiryani, Fifik, and Nurhasan Ismail, 'Penerapan Prinsip Partisipatif Dan Keadilan Sosial Dalam Pengaturan Dan Pelaksanaan Pengadaan Tanah Bagi Pembangunan Untuk Kepentingan Umum' (Universitas Gadjah Mada, 2016)

Wiryani, Fifik, Mokhammad Najih, and Abdul Haris, 'Juridical Analysis On Consumer Protection In Safe and Halal', Dinamika Hukum, $18.1 \quad$ (2018), 20-29 <https://doi.org/http://dx.doi.org/10.20884/1.jdh.2018.18.1.1586> 
Xanthaki, Alexandra, 'Lands Rights of Indigenous Peoples in South East Asia', Melbourne Journal of International Law, 4.1 (2003), 467-95

Yusrizal, Muhammad, 'Perlindungan Hukum Pemegang Hak Atas Tanah Dalam Pengadaan Tanah Untuk Kepentingan Umum', De Lega Lata, 2.1 (2017), 113-38

Zakie, Mukmin, 'Konflik Agraria Yang Tak Pernah Reda', Legality: Jurnal Ilmiah Hukum, 24.1 (2017), 40 <https://doi.org/10.22219/jihl.v24i1.4256>

-, 'Pengadaan Tanah Untuk Kepentingan Umum (Perbandingan Antara Malaysia Dan Indonesia)', Jurnal Hukum Edisi Khusus, 18 (2011), 187-206 